Theme: Shape Memory Alloy

\title{
THE EVOLUTION OF INTERNAL VOLUMETRIC DEFECTS IN THE WIRE DRAWING PROCESS OF NiTi*
}

\author{
Osmar de Sousa Santos ${ }^{1}$ \\ André da Silva Antunes ${ }^{2}$ \\ Odair Doná Rigo ${ }^{3}$ \\ Jorge Otubo 4
}

\begin{abstract}
$\mathrm{NiTi}$ shape memory alloys (SMA) have been widely used as construction materials due to their shape memory and superelastic properties. Usually the application of the $\mathrm{NiTi}$ alloy is in the wire form, which is ideal shape to make springs, orthodontic arcwire and endodontic files. Since our research group (ITASMART) started producing $\mathrm{NiTi}$ wires, it was noticed that NiTi SMA produced by Vacuum Induction Melting (VIM) presents carbon contamination, which is due to the melting process. Therefore, alloys rich in carbon remove titanium from matrix, forming precipitates of $\mathrm{TiC}$ (titanium carbide). Also, $\mathrm{Ti}_{2} \mathrm{Ni}$ precipitation removes titanium from the matrix and these two precipitates $\mathrm{TiC}$ and $\mathrm{Ti}_{2} \mathrm{Ni}$ can produce internal volumetric defect in the wire drawing process. Seeing the importance of $\mathrm{NiTi}$ wires as base of many applications, this work studies the formation of volumetric defects caused by precipitates in the wire drawing process of a NiTi wire drawn down to $0,39 \mathrm{~mm}$ in diameter.
\end{abstract}

Keywords: NiTi SMA; TiC precipitate; $\mathrm{Ti}_{2} \mathrm{Ni}$, Wire drawing.

1 Physicist, MSc., student, ITASMART, Mechanical Engineering, Instituto Tecnológico de Aeronautica, São José dos Campos, SP, Brazil.

2 Physicist, MSc., student, ITASMART, Mechanical Engineering, Instituto Tecnológico de Aeronautica, São José dos Campos, SP, Brazil.

3 Materials Engineerings, BSc, research, Materials, Nuclear Energy, Centro Tecnológico da Marinha, São Paulo, SP, Brazil.

4 Physicist, PhD., professor, ITASMART, Mechanical Engineering, Instituto Tecnológico de Aeronautica, São José dos Campos, SP, Brazil.

\footnotetext{
* Technical contribution to the $69^{\text {th }}$ ABM International Annual Congress and to the ENEMET, July $21^{\text {st }}-25^{\text {th }}$, 2014, São Paulo, SP, Brazil.
} 


\section{INTRODUCTION}

Shape Memory Alloys (SMA) have applications in various fields of human activity: aerospace, automotive, nuclear, robotics, medical and others [1-6]. It is considered a strategic material and its import is severely hampered by technology holder's countries. Thus, developing national technology both production and forming as well as tailor made applications of the alloys is critical to the country's development in the area. Today ITASMART group (acronym for ITA - Shape Memory Alloys Research and Technology) have mastered the technology of manufacturing the alloy NiTi, not by one but by three processes (Vacuum Induction Melting - VIM; Vacuum Arc Remelting under inert atmosphere - VAR and Electron Beam Melting - EBM). By the time the ITASMART produced approximately 70 ingots with different compositions of nickel/titanium, carbon and oxygen, with masses ranging from $100 \mathrm{~g}$ to $22 \mathrm{~kg}$ [7-19]. Among various existing applications for NiTi SMA, highlight applications using wire, were the material can be readily deformed by applying an external force, and will contract or recover to its original form when heated beyond a certain temperature either by external or internal heating (Joule heating). Therefore, straight SMA wires are more advantageous due to the optimal use of material (i.e. more work generated from a minimal amount of SMA material) and the loading in tension configuration [20].

$\mathrm{NiTi}$ wires can be obtained through the drawing process, which allows to obtain wires with long length and constant cross-section, with controlled mechanical properties [21]. In order to obtain a wire of NiTi with controlled mechanical properties is very important to control the chemical composition of the alloy in terms of contamination of carbon. Previous works, undertaken by ITASMART, showed that the carbon contamination is inherent to VIM process due to melting in a graphite crucible and highly dependence on the quality of the graphite as well as the size of the crucible used [11-16]. Therefore, alloys rich in carbon remove titanium from matrix, forming TiC precipitates (titanium carbide) and as a consequence, it changes the wire thermomechanical properties.

Contributes to titanium removal of the matrix the $\mathrm{Ti}_{2} \mathrm{Ni}$ precipitate formation, where the titanium is removed from the matrix in a 2:1 ratio. The $\mathrm{Ti}_{2} \mathrm{Ni}$ is a fragile precipitate, thus tends to form a fragmented and elongated precipitate in the wire drawing direction [22-24]. Seeing the importance of NiTi wires as base of many applications, this work studies the formation of volumetric defects caused by precipitates in the wire drawing process of a NiTi wire.

\section{MATERIAL AND METHODS}

The starting material was a wire of $1.00 \mathrm{~mm}$ in diameter produced by ITASMART. The wire was cold drawn to $0.398 \mathrm{~mm}$ with $15 \%$ of area reduction per pass, interspersing annealing at $750^{\circ} \mathrm{C}$ for 3 minutes.

The drawing was made in a monobloc wire drawing and heat treatments annealing between passes in a Havi Duty furnace at the ITASMART facilities, Figure 1.

\footnotetext{
* Technical contribution to the $69^{\text {th }}$ ABM International Annual Congress and to the ENEMET, July $21^{\text {st }}-25^{\text {th }}$, 2014, São Paulo, SP, Brazil.
} 

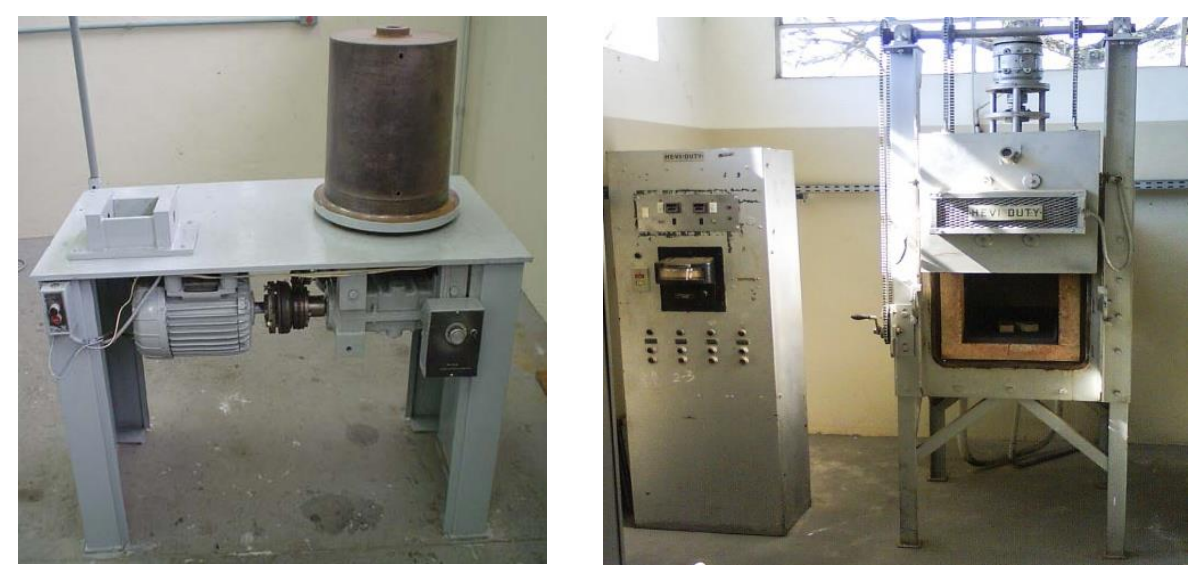

Figure 1. Monobloc wire drawing and Havi Duty furnance (from the left to right).

A set of dies with tungsten carbide core and as a grease lubricant molybdenum disulfide $\left(\mathrm{MoS}_{2}\right)$ was used in drawing. The Table 1 shows the values for dies used in each drawing pass and the Figure 2 shows the wire with $0.398 \mathrm{~mm}$.

Table 1. Set of dies.

\begin{tabular}{cc}
\hline Drawing pass & Diameter $(\mathrm{mm})$ \\
\hline $1^{\text {st }}$ & 0.990 \\
\hline $2^{\text {nd }}$ & 0.910 \\
\hline $3^{\text {rd }}$ & 0.830 \\
\hline $4^{\text {th }}$ & 0.760 \\
\hline $5^{\text {th }}$ & 0.700 \\
\hline $6^{\text {th }}$ & 0.640 \\
\hline $7^{\text {th }}$ & 0.590 \\
\hline $8^{\text {th }}$ & 0.540 \\
\hline $9^{\text {th }}$ & 0.490 \\
\hline $10^{\text {th }}$ & 0.398 \\
\hline
\end{tabular}

The metallographic samples were cut with refrigerated diamond saw with controlled load in order to minimize residual stress and also to avoid mechanically induced martensite. Then the samples were molded in Bakelite, grinded down to 1200 grit sandpaper with automatic grinding/polishing machine (Allied Metrep3).

To analyses the microstructure the samples were etched with a solution of $50 \mathrm{ml} \mathrm{H}_{2} \mathrm{O}$ $+40 \mathrm{ml} \mathrm{HNO} 3+10 \mathrm{ml} \mathrm{HF}$ for a period of 15 seconds. The microstructure of the samples was observed and analyzed with scanning electron microscopy - SEM (Tescan, model Vega $3 \mathrm{XMU}$ ), energy dispersive spectroscopy - EDS (Oxford Instruments, model X-Act SDD EDS detector) and AZtec EDS analysis software (Oxford Instruments).

\footnotetext{
* Technical contribution to the $69^{\text {th }}$ ABM International Annual Congress and to the ENEMET, July $21^{\text {st }}-25^{\text {th }}, 2014$, São Paulo, SP, Brazil.
} 

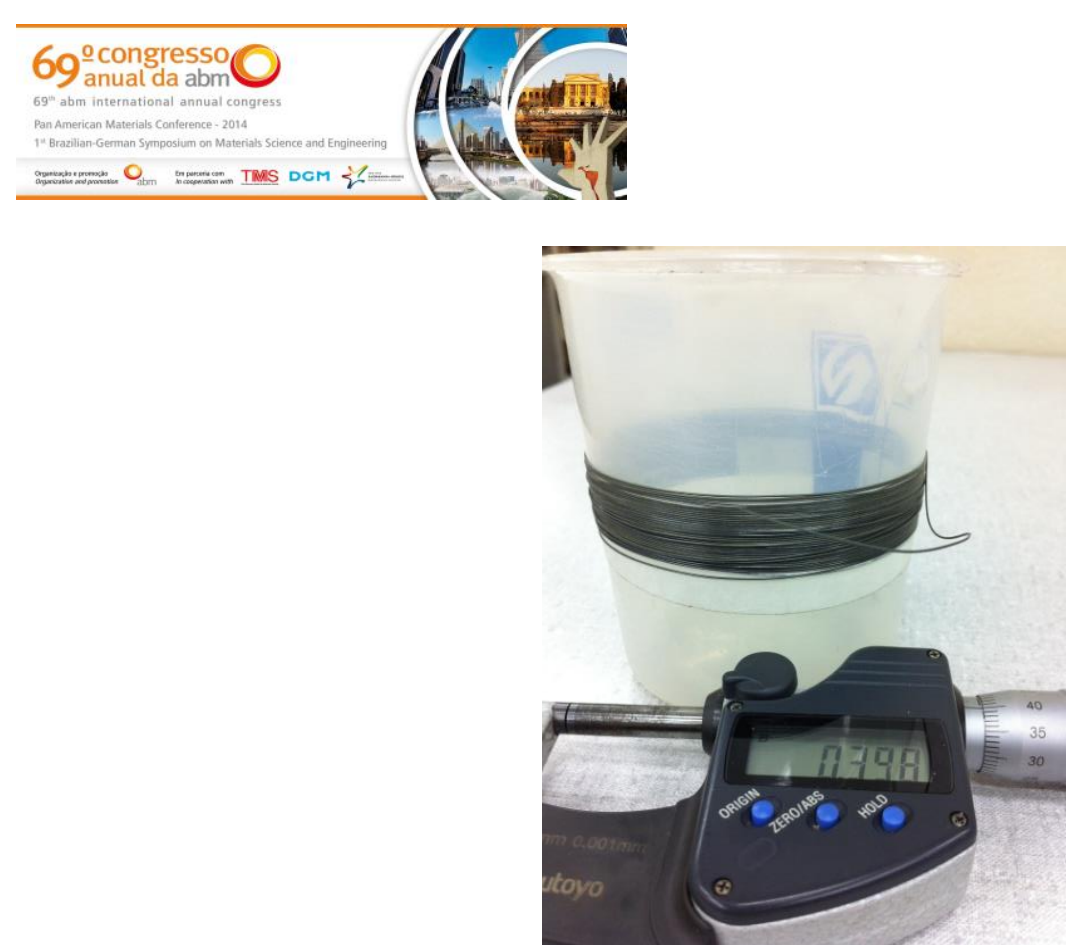

Figure 2. Wire of NiTi with $0.398 \mathrm{~mm}$ in diameter.

\section{RESULTS AND DISCUSSION}

The Table 2 shows the values found for the overall chemical composition of the alloy used to produce the wire.

Table 2. Chemical composition of the alloy NiTi and its MTT.

\begin{tabular}{cccccccc}
\hline $\mathrm{Ni}$ & $\mathrm{C}$ & $\mathrm{Ms}$ & $\mathrm{Mp}$ & $\mathrm{Mf}$ & $\mathrm{As}$ & $\mathrm{Ap}$ & $\mathrm{Af}$ \\
$(\%$ at $)$ & $(\% w t)$ & $\left({ }^{\circ} \mathrm{C}\right)$ & $\left({ }^{\circ} \mathrm{C}\right)$ & $\left({ }^{\circ} \mathrm{C}\right)$ & $\left({ }^{\circ} \mathrm{C}\right)$ & $\left({ }^{\circ} \mathrm{C}\right)$ & $\left({ }^{\circ} \mathrm{C}\right)$ \\
\hline 49,42 & 0.066 & 62.5 & 51.2 & 38.0 & 65.3 & 81.9 & 91.0 \\
\hline
\end{tabular}

The analysis matensitic transformation temperatures (MTT) of the NiTi alloy shows that the alloy is in the martensitic phase at room temperature. Where, Ms (start of temperature transformation of direct martensitic), $\mathrm{Mp}$ and $\mathrm{Mf}$ (final temperature of the direct Martensitic Transformation - MT) are above room temperature. Even temperatures of reverse MT such as As (temperature at the beginning of the reversion of martensite to austenite), Ap (peak of temperature of the reversion of martensite to austenite) and Af (final temperature of the reversion of martensite to austenite) are above room temperature.

As we can see in Table 2 the alloy has high carbon content $(0.066 \%$ wt) and as result the carbon remove titanium from matrix, forming precipitates of TiC (titanium carbide), in the Figure 3 it is possible to see the results for the EDS measurements of the wire with $0.39 \mathrm{~mm}$ in diameter.

The upper ward of Figure 3 shows the shift in chemical composition to the linescan measurement, this change in chemical composition clearly indicates that the precipitated formed is TiC. Thus, the maps in the bottom of the Figure 3 confirm the presence of titanium and carbon in the precipitate, in other words TiC, where the region in black of the maps indicates lack of chemical elements.

\footnotetext{
* Technical contribution to the $69^{\text {th }}$ ABM International Annual Congress and to the ENEMET, July $21^{\text {st }}-25^{\text {th }}$, 2014, São Paulo, SP, Brazil.
} 
The Figure 5 shows micrographs taken in the SEM of wires with $1,00 \mathrm{~mm}$ and 0.398 $\mathrm{mm}$ in diameter, respectively. The micrographs were taken with the horizontal direction coinciding with the direction of drawing.

By the analyses of the micrographics of Figure 5 is possible to observe that precipitates in wire with $1.00 \mathrm{~mm}$ in diameter are distributed more widely spaced from each other along the wire if compared to distribution of precipitates from the wire with $0.398 \mathrm{~mm}$ in diameter. Therefore, as we can see by the micrographic, the precipitates of wire with $0.398 \mathrm{~mm}$ in diameter are more clusters along the wire.

One can note that the precipitates are aligned in the longitudinal direction of the wire showing the deformation texture and the reduction in diameter from $1.00 \mathrm{~mm}$ to $0.398 \mathrm{~mm}$ causes a significant increase in the trail left by precipitates along the drawing direction. This result suggests that while the wire is wire drawing to smaller diameters, there is an increase in formation of volumetric defects inside the wire.
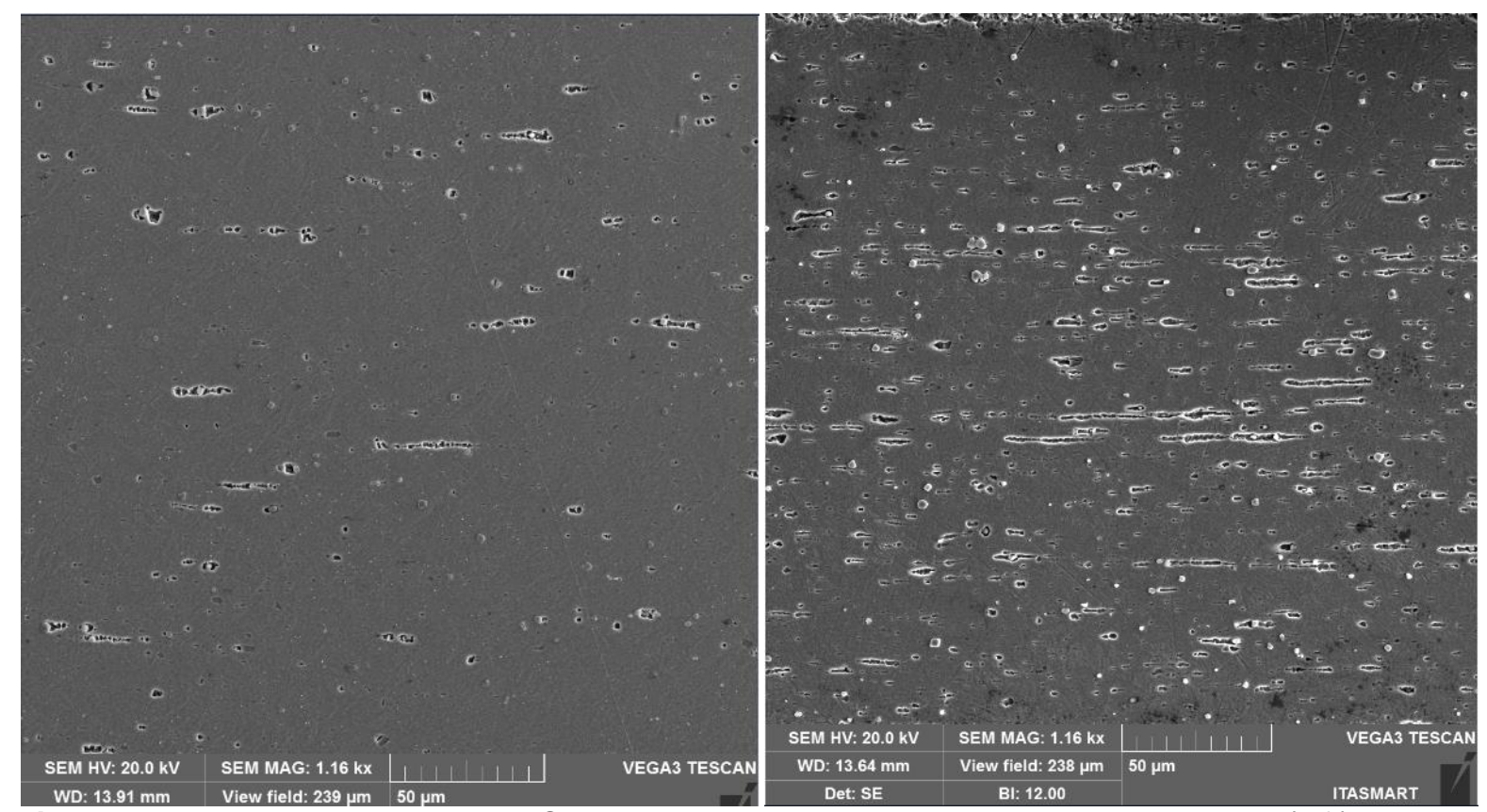

Figure 5. Micrographs taken in the SEM showing: NiTi wire with $1.00 \mathrm{~mm}$ in diameter (left); NiTi wire with $0.398 \mathrm{~mm}$ in diameter (right).

\section{CONCLUSION}

Wires produced by NiTi alloys with high contents of carbon show precipitates that tend to cluster inside the wire by the wire drawing process. Nevertheless, as much as the wire is wire drawing to smaller diameters the precipitates tend to align in the direction of drawing.

We notice that along the wire drawing direction occurs the fragmentation of $\mathrm{Ti}_{2} \mathrm{Ni}$ precipitates, leaving a trail of volumetric defect inside the wire.

The amount of volumetric defects inside the wire of $1.00 \mathrm{~mm}$ in diameter is smaller if compared to the amount found to wire with $0.398 \mathrm{~mm}$ in diameter. Therefore, it is possible to infer that the more is the number of wire drawing passes in a NiTi wire with high amount of precipitates, the more is the amount of volumetric defects produced inside the wire.

\footnotetext{
* Technical contribution to the $69^{\text {th }} A B M$ International Annual Congress and to the ENEMET, July $21^{\text {st }}-25^{\text {th }}$, 2014, São Paulo, SP, Brazil.
} 


\section{Acknowledgments}

To CAPES for the doctoral scholarship of the author. To FAPESP for the infrastructure and equipment (grant 00/09730-1), to Universal CNPq (grant 473612/2006-2), to FINEP, PRO-INFRA and to AEB to supporting this project.

\section{REFERENCES}

1 Liu Y, Humbeeck JV, Stalmans R, Delaey. Some aspects of the properties of NiTi shape memory alloy. Journal of Alloys and Compounds, 1997; 247, $115-121$.

2 Jackson CM, Wagner HJ, Wasilewski RJ. 1972, 55-Nitinol - The alloy with memory: its physical metallurgy, properties, and applications, NASA-SP 5110.

3 Burstone CJ, Qin B, Morton JY. 1985, Chinese NiTi wire - A new orthodontic alloy, American Journal of Orthodontics, 87, 445-452.

4 Busch JD, Purdy WE, Johnson AD. 1992, Development of a non-explosive device for aerospace applications, $26^{\text {th }}$ Aerospace Mechanisms Syposium, 1-16.

5 Funakubo H., Shape Memory Alloys, Ed. Hiroyasu Funakubo, University of Tokyo, 1987.

6 Duerig T, Pelton A, Trepanier C. Nitinol. ASM International, SMST e-Elastic Newslatter, 2009.

7 Otubo J, Mei PR, Koshimizu S, Martinez ELG. 1998, NiTi shape memory alloys produced by electron beam melting: preliminary results, The Third Pacific Rim International Conference on Advanced Materials and Processing - PRICM-3, July 12-16, 1998, Honolulu, Hawaii, USA, vol.1, 1063-1068, Edited by M. A. Imam, R. DeNale, S. Hanada, Z. Zhong and D. N. Lee, publicado pela The Minerals, Metals \& Materials Society, TMS.

8 Otubo J, Rigo OD, Moura Neto C, Mei PR. Produção de lingotes da liga NiTi com efeito de memória de forma em forno de fusão por feixe eletrônico, 55으 Congresso da ABM, 24 a 28 de julho de 2000, Rio de Janeiro, RJ;

9 Otubo J, Rigo OD, Moura Neto C, Kaufman MJ, Mei PR, 2000b, Scale up on NiTi SMA production by EBM, Presented at International Conference on Martensitic

Transformation, ICOMAT'02, 9 to 14 June, Espoo, Finland, published in Journal de Physique IV.

10 Otubo J, Rigo OD, Moura Neto C, Kaufman MJ, Mei PR. NiTi SMA ingot production by EBM, 15 CBECIMAT, 9 a 13 de Novembro de 2002, Natal, RN.

11 Otubo J, Rigo OD, Moura Neto C, Kaufman MJ, Mei PR, 2002b, The use of ceramic filter for TiC removal from NiTi shape memory alloy during pouring, 15 CBECIMAT, 9 a 13 de Novembro de 2002, Natal, RN.

12 Otubo J, Rigo OD, Moura Neto C, Kaufman MJ, Mei PR. Scale up of NiTi shape memory alloy production by EBM, J. Physique, IV France, 112, 2003, pp. 873-876.

13 Otubo J, Rigo OD, Moura Neto C, Kaufman MJ, Mei PR. Low carbon content shape memory alloy produced by electron beam melting, Materials Research, 2004; 7(2): 263267.

14 Otubo J, Rigo OD, Moura Neto C, Mei PR. The effects of VIM and EBM processing techniques on the purity of NiTi SMA, Materials Science and Engineering A, 2006; 430440: 679-672.

15 Otubo J, Rigo OD, Moura Neto C, Mei PR. The influence carbon and oxygen on the martensitic transformation temperatures and enthalpies of NiTi ahape memory alloy, Materials Science and Engineering A, 2008; 481-482: 639-642.

16 Rigo OD, Otubo J, Moura Neto C, Kaufman MJ, Mei PR. O efeito da qualidade do cadinho de grafite e de suas dimensões sobre o grau de contaminação por carbono na liga NiTi com EMF processado no VIM", 15 CBECIMAT, 9 a 13 de Novembro de 2002, Natal, RN.

\footnotetext{
* Technical contribution to the $69^{\text {th }}$ ABM International Annual Congress and to the ENEMET, July $21^{\text {st }}-25^{\text {th }}$, 2014, São Paulo, SP, Brazil.
} 


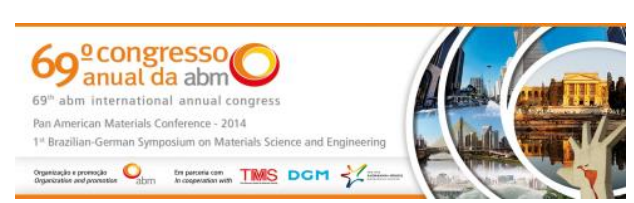

17 Rigo OD, Otubo J, Moura Neto C, Mei PR. Determinação de temperaturas de transformação martensítica em ligas de NiTi com EMF por captura de imagens, II Workshop sobre Textura e Relações de Orientação, 8 e 9 de Dezembro de 2003 IPEN, São Paulo, SP.

18 Rigo OD, Otubo J, Mei PR. Influência do teor de níquel nas temperaturas de transformação martensítica da liga NiTi com Efeito de Memória de Forma, 60으 Congresso Anual da ABM, Belo Horizonte, MG, 25 a 28 de Julho de 2005.

19 Rigo OD, Otubo J, Mei PR. NiTi SMA production using ceramic filter during pouring the melt", Journal of Materials Processing Technology, 162-163 (2005) 116-120.

20 Jani JM, Leary M, Subic A, Gibson MA. A review of shape memory alloy research, applications and opportunities, Materials and Design, 2014; 56: 1078-1113.

21 Pelton A, Dicello J, Miyazaki S. Optimization of processing and properties of medicalgrade Nitinol wire. Proceedings of the International Conference on Shape Memory and Superelastic Technologies SMST 2000, ed S. Russel, A. Pelton, 361-374, accessed in September, 12, 2008.

22 Jiang S, Zhao Y, Zhang Y, Hu L, Liang Y. Effect of solution treatment and aging on microstructural evolution and mechanical behavior of NiTi shape memory alloy. Trans. Nonferrous Met. Soc. China, 2013; 23: 3658-3667. DOI: 10.1016/S10036326(13)62914-3.143

23 Frenzela J, George EP, Dlouhy A, Somsen Ch, Wagner MF-X, Eggeler G. Influence of $\mathrm{Ni}$ on martensitic phase transformations in NiTi shape memory alloys. Acta Materialia, 2010; 58: 3444-3458. doi:10.1016/j.actamat.2010.02.019

24 Mentz, J, Frenzel J, Wagner MF-X, Neuking K, Eggeler G, Buchkremer HP, Stöver D. Powder metallurgical processing of NiTi shape memory alloys with elevated transformation temperatures, Materials Science and Engineering: A, 2008; 491: 270278, doi: org/10.1016/j.msea.2008.01.084

* Technical contribution to the $69^{\text {th }} A B M$ International Annual Congress and to the ENEMET, July $21^{\text {st }}-25^{\text {th }}$, 2014, São Paulo, SP, Brazil. 